\title{
THE APPLE-MATRIX EFFECT ON GC/MS RESPONSE OF CYPRODINIL, PYRIMETHANIL AND TRIFLOXYSTROBIN STANDARDS
}

\author{
Milica D. Branković ${ }^{\star}$, Darko H. Anđelković ${ }^{1}$, Hristina R. Kocić2 ${ }^{\text {, Gordana M. Kocić2 }}$
}

1 University of Niš, Faculty of Science and Mathematics, Department of Chemistry, Niš, Serbia

${ }^{2}$ Faculty of Medicine, University of Niš, Niš, Serbia

Gas or liquid chromatography coupled with mass spectrometry is among the most reliable analytical techniques used in pesticide residue analysis. The existing problem in pesticide analysis in complex matrices such as fruit is the variation in analyte chromatographic response caused by matrix components, which is called the matrix effect. These effects can be evaluated quantitatively by comparing the response of equal analyte concentrations in a solvent and in the post extraction fortified sample extract. The response of the $5 \mu \mathrm{g} \mathrm{mL}^{-1}$ solution of fungicides pyrimethanil, cyprodinil, from the class of anilinopyrimidines and trifloxystrobin from the class of strobilurins, commonly used in the protection of apple crops, was evaluated in pure hexane and in different concentrations of peel and flesh hexane extracts of Granny Smith apple variety. The response of trifloxystrobin was not significantly changed in either of two matrices, while a significantly more different response of pyrimethanil and cyprodinil was observed in both peel and flesh extracts than in the pure solvent. In the undiluted flesh extract, the matrix effect reached $154 \%$ and $76 \%$ for pyrimethanil and cyprodinil, respectively. In the undiluted peel extract, the values were $-49 \%$ for pyrimethanil and $-30.2 \%$ for cyprodinil. The response variation of these pesticides remained high, even after the matrix dilution. The final matrix dilution resulted in about 2-times lower response variation for both pesticides in flesh extract-based standards, while in peel extract-based standards the manifestation of inversion was observed.
(ORIGINAL SCIENTIFIC PAPER) UDC 632.95.02:543.5:634.11

Keywords: GC/MS; single-level concentration; matrix effect; apples

\section{Introduction}

Gas chromatography coupled to mass spectrometry has been widely used in the analysis of pesticides in many matrices, such as fruit and vegetables. The existing problem in pesticide analysis in such complex matrices is the variation in their chromatographic response caused by matrix components, which is called the matrix effect. This phenomenon is nowadays used as an explanation for pesticide recovery rates exciding $100 \%$ and low accuracy of the results. According to IUPAC, the matrix effect represents "the combined effect of all components of the sample other than the analyte on the measurement of the quantity" [1], and it is considered to be the result of the analyte - co-extractives interactions in different parts of GC, mainly in the injector and chromatography column or in the detector [2]. As a result, the analyte signal can be enhanced - a positive matrix effect or suppressed - a negative matrix effect.

The accepted explanation for the positive matrix effect or the phenomenon called "matrix induced chromatographic response enhancement effect" is that the coextractives "compete" with the analytes for the injector active sites, causing the transfer of a larger amount of analyte to the column [3], while the negative matrix effect, usually called "induction of the decrease of the response by the matrix" occurs when non-volatile components of the matrices accumulate in the injector or in the column, resulting in the formation of new active sites, to which analyte can also attach, causing the transfer of a smaller amount to the chromatographic column [4].

Pesticide residue analysis in apples has a great significance, since due to the broad consumption apples are among the most treated fruits against pests and can be found on the market throughout the whole year. As matrices, apples consist of various components including organic and amino acids, sugars, phenolic compounds and fatty acids (C18 family) [5,6].

Due to many differences in the composition of apple peel and flesh [7], they can be considered as different types of matrix. Since it was observed that the same pesticide can express different chromatographic responses depending on the matrix [8], the aim of this study was to evaluate the GC/MS response of trifloxystrobin, pyrimethanil and cyprodinil, fungicides commonly used in the protection of apple crops, in different concentrations of peel and flesh extracts of the selected apple variety.

\footnotetext{
*Author address: Milica Branković, University of Niš, Faculty of Science and Mathematics, Department of Chemistry,

Višegradska 33, 18000 Niš, Serbia

E-mail: milica.chem@outlook.com

The manuscript received: November, 11, 2018.

Paper accepted: December, 01, 2018.
} 


\section{Experimental}

\section{Chemicals}

High purity pesticide standards of pyrimethanil, cyprodinil and trifloxystrobin were purchased from Accu Stand$\operatorname{ard} \circledast$ (New Haven, CT, USA). Dibutyl adipate (DBA) was purchased from Sigma Aldrich (St Louis, MO, USA). HPLC grade hexane was purchased from Fisher Scientific (USA).

\section{Standard preparation}

Individual stock solutions were made of high purity pesticide standards at the concentration of $1000 \mu \mathrm{g} \mathrm{mL}^{-1}$ in hexane and stored in a freezer at $-15^{\circ} \mathrm{C}$. The mixed stock solution of pesticides (working solution) was prepared in hexane by mixing individual stock solutions, with the final concentration of trifloxystrobin, pyrimethanil and cyprodinil of $50 \mu \mathrm{g} \mathrm{mL}-1$. Injection solutions with the final concentration of pesticides of $5 \mu \mathrm{g} \mathrm{mL}-1$ were prepared using the working solution, according to the procedure described in the section Matrix effect evaluation procedure. Internal standard solution (ISTD) was prepared by dissolving pure DBA in hexane to the concentration of $10 \mu \mathrm{g} \mathrm{mL}^{-1}$.

\section{Samples}

Apples of Granny Smith variety were randomly chosen from a green market. Apple fruits were free of visible damages and pests. A screening analysis of peel and flesh did not show the presence of the tested pesticides.

Sample extract preparation

One hundred grams of the sample taken from 3 separate apple fruits was peeled and afterwards blended for matrix effect evaluation in peel and flesh. Ten grams $(10 \pm 0.01 \mathrm{~g})$ of blended subsample was transferred to a glass container. Afterwards, $10 \mathrm{~mL}$ of hexane was added, and the extraction by shaking was performed. The obtained extracts were then transferred to glass cone tubes and centrifuged for $10 \mathrm{~min}$ at $3800 \mathrm{rpm}$. The upper hexane layer was separated from the solids-water dispersion and used for further experiment. Since the solvent/sample ratio in the extraction procedure was $1 \mathrm{~mL}$ of the solvent per gram of the sample, a presumed value for the matrix concentration in the obtained hexane extract was $1 \mathrm{~g} \mathrm{~mL}^{-1}$.

\section{GC-MS analysis}

Gas chromatographic analysis was performed on Agilent 6890 gas chromatograph equipped with 5973 Mass Selective Detector (MSD), 7683 Autosampler and SGE 25QC2/BPX5 0.25 capillary column ( $25 \mathrm{~m} \times 0.22 \mathrm{~mm} \times 0.25 \mu \mathrm{m}$, non-polar). The mass spectra were recorded under an electron impact ionization (El) voltage of $70 \mathrm{eV}$. The gas chromatograph was operated in the splitless injection mode. The oven temperature was programmed from $90^{\circ} \mathrm{C}$ (hold time 0 $\min )$ to $280{ }^{\circ} \mathrm{C}(4 \mathrm{~min})$ at $20^{\circ} \mathrm{C} \mathrm{min}-1$ rate; post run: $300{ }^{\circ} \mathrm{C}$ (2 min). Helium was the carrier gas with the constant flow rate of $1.0 \mathrm{~mL} \mathrm{~min}^{-1}$. Analytes responses were normalized to DBA as internal standard. The MSD was used in the single ion-monitoring mode (SIM) at $m / z$ as given in Table 1 . and $m / z 185$ for DBA. The identification and quantification of target compounds was based on the relative retention time, the presence of target ions and their relative abundance. Both data acquisition and processing were accomplished by Agilent MSD Chem Station $®$ D.02.00.275 software.

Table 1. Properties and qualification parameters of the tested pesticides (quantifier ion is shown in bold)

\begin{tabular}{ccccccc}
\hline \multirow{2}{*}{ Pesticide } & \multirow{2}{*}{ Class } & \multirow{2}{*}{ Structure } & $\begin{array}{c}\text { Molecular } \\
\text { mass }\end{array}$ & $\begin{array}{c}\text { Log } \\
\text { Kow }\end{array}$ & $\begin{array}{c}\text { Retention time, } \\
\text { min }\end{array}$ & $\begin{array}{c}\text { Target ions, } \\
\mathrm{m} / \mathbf{z}\end{array}$ \\
\hline Pyrimethanil & Fungicide & Anilinopyrimidine & 199.25 & 2.84 & 6.79 & $\mathbf{1 9 8}^{\mathrm{a}}$ \\
Cyprodinil & Fungicide & Anilinopyrimidine & 225.28 & 3.59 & 8.07 & $\mathbf{2 2 4}^{\text {a }}$ \\
Trifloxystrobin & Fungicide & Strobilurin & 408.37 & 4.50 & 9.25 & $\mathbf{1 1 6 , 1 3 1 , 1 4 5}$ \\
\hline \multicolumn{7}{l}{ a Besides ions specified in the Table, El ionization of pesticide molecules do not give other specific fragments }
\end{tabular}

Matrix effect evaluation procedure

The signal of $5 \mu \mathrm{g} \mathrm{mL}-1$ pesticides standard solution prepared with different volumes of peel and flesh extracts of Granny Smith apple variety was examined, and its variation was evaluated by means of the matrix effect. First, the injection solution was prepared in hexane by mixing $100 \mu \mathrm{L}$ of ISTD solution, $100 \mu \mathrm{L}$ of the working pesticide solution $\left(50 \mu \mathrm{g} \mathrm{mL}^{-1}\right)$ and $800 \mu \mathrm{L}$ of the pure solvent. Other three injection solutions were prepared by mixing $100 \mu \mathrm{L}$ of ISTD solution, $100 \mu \mathrm{L}$ of the working pesticide solution and $800 \mu \mathrm{L}, 200 \mu \mathrm{L}$ and $100 \mu \mathrm{L}$ of hexane extracts of apple peel and flesh, afterwards filled up to $1000 \mu \mathrm{L}$ with hexane, resulting in dilution factors of $1.25,5$ and 10 , respectively, aimed for the evaluation of the response behavior of the pesticide with the matrix dilution. So, the matrix concentration in diluted extracts was $0.8 \mathrm{~g} \mathrm{~mL}^{-1}$ (DF 1.25), $0.2 \mathrm{~g} \mathrm{~mL}^{-1}$ (DF 5) and $0.1 \mathrm{~g} \mathrm{~mL}^{-1}$ (DF 10).
The matrix effect $(M E)$ was calculated by relating the response of the pesticides standard obtained by the dilution of standards in apple extracts $(R 1)$ to the response of the standard prepared in pure hexane $(R 2)$ using the following equation:

$$
M E, \%=\frac{R_{1}-R_{2}}{R_{2}} \times 100
$$

Positive percentage indicates signal enhancement and negative percentage - signal suppression. Due to the closeness to the repeatability values, the percentage values between $-20 \%$ and $20 \%$ do not indicate the matrix effect. The values between $-50 \%$ and $-20 \%$ or $20 \%$ and $50 \%$ indicate the medium matrix effect and below $-50 \%$ or above $+50 \%$ strong matrix effect [9].

Dilution factor $(D F)$ was calculated as: 


$$
D F=\frac{V_{f}}{V_{i}}
$$

where $\mathrm{Vi}$ is the volume of the sample extract taken for dilution and $V f$ is the final volume after dilution. The dilution of the sample extract caused by adding the internal standard and the pesticide stock solution (DF 1.25) is unavoidable and considered.

\section{Results and discussion}

Figure 1. represents the variation in the signal response of the $5 \mathrm{\mu g} \mathrm{mL}^{-1}$ pesticide standard solution prepared with different volumes of the hexane extract of Granny Smith flesh, resulting in different matrix concentrations. With increasing the matrix dilution a linear decrease of the matrix effect values can be observed for all pesticides. By extrapolation of curves, the matrix effect in undiluted extract could be calculated - values of $154 \%$ for pyrimethanil and $76 \%$ for cyprodinil indicate a strong positive matrix effect i.e. great signal enhancement. For trifloxystrobin, the medium matrix effect was observed with the value of $38 \%$. After 10 -fold dilution, the matrix effect values reached $70 \%$ for pyrimethanil and $44 \%$ for cyprodinil, while for trifloxystrobin the matrix effect can be considered eliminated (5.7\%).

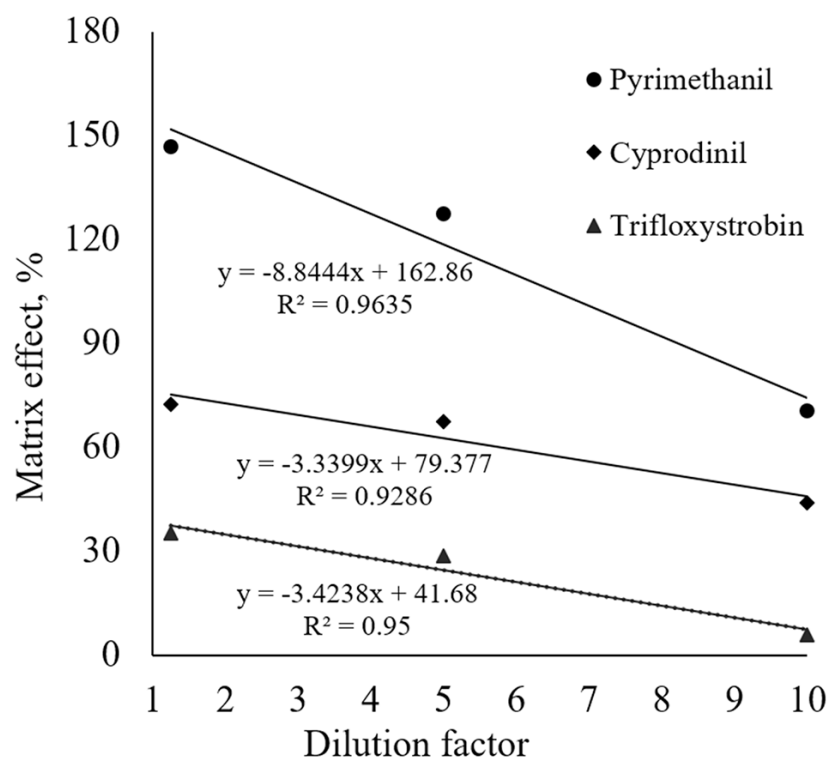

Figure 1. The dependence of the matrix effect on a dilution factor for the flesh extract-based standard

For pesticides standard prepared with different volumes of Granny Smith peel extract, the matrix effect trendline is logarithmic (Figure 2). Extrapolation of curves for pyrimethanil and cyprodinil displayed negative matrix effect values i.e. signal suppression of these pesticides in the undiluted peel extract. The response of trifloxystrobin was not affected i.e. there was no notice- able matrix effect. With dilution, the matrix effect moved towards positive values, making an inversion. After 10fold dilution, matrix effect values reached 104\%, 56\% and $25 \%$ for pyrimethanil, cyprodinil and trifloxystrobin, respectively.

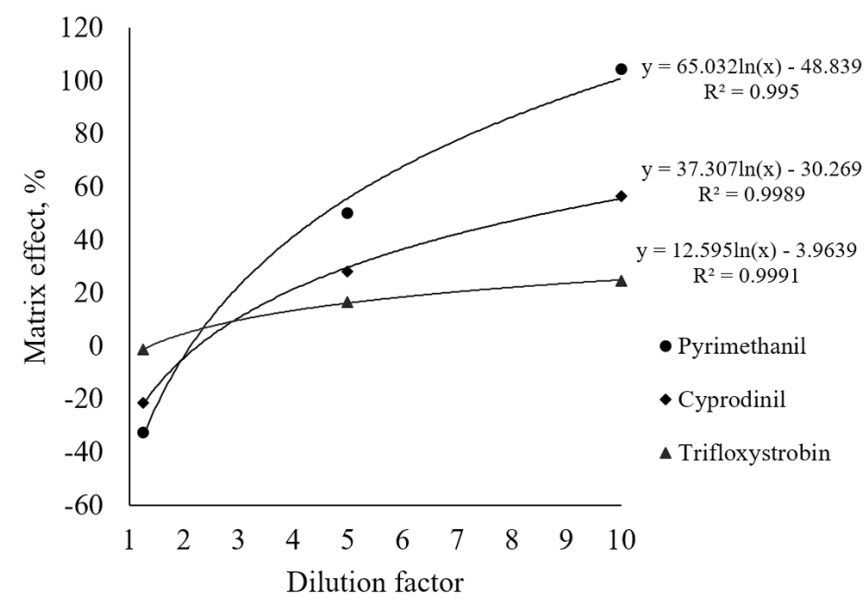

Figure 2. The dependence of the matrix effect on a dilution factor for the peel extract-based standard

Matrix effects are in general more pronounced for more polar pesticides [10]. Therefore, higher response variation was observed for more polar pyrimethanil than for cyprodinil and trifloxystrobin. In fact, the response of trifloxystrobin can be considered unaffected in both matrices. Matrix effect - dilution trendline is similar for all pesticides. Another study, dealing with the response of several pesticides in the apple matrix, demonstrated the dependence of the matrix effect on the matrix concentration - a gradual increase in response of dimethoate, chlorothalonil and fenitrothion was observed, as the matrix concentration in the solutions increased from 0.1 to $1.0 \mathrm{~g} \mathrm{~mL}^{-1}$ [11]. The study furthermore revealed that besides matrix concentration, the matrix effect depends on the matrix type, pesticide concentration and analytical range.

The difference in matrix effect values in undiluted Granny Smith peel and flesh extracts, and even more the inversion might be explained by means of apple waxes and their much higher amount in the apple peel than in the apple flesh. Apple fruits possess a cuticle with the mixture of $\mathrm{C} 16-\mathrm{C} 18$ chained compounds mainly composed of saturated and unsaturated dihydroxy hexadecenoic, trihydroxy and epoxy hydroxy octadecanoic acids and a triterpenoid-rich cuticular wax mixture [12] In one study, a significant relationship between triterpenic acids (oleanolic and ursolic acids) was recognized, found in much higher concentrations in the apple peel than in the flesh, and a negative matrix effect in GC/ $M^{2}$ [13]. The most abundant components of the peel wax of Granny Smith variety are compounds such as pentacosane, nonacosane and unsaturated fatty acids like C20:3n6, C18:2n6, C18:3n3, C22:2, C14:1, C16:1 [14]. Chromatograms of blank Granny Smith peel and flesh extracts (not shown here) were similar in profile, 
but with a much higher content of compound eluting at 12.37 minutes in the peel than in the flesh extract. This compound could be attributed to the group of apple waxes, since the mass spectra mainly consisted of aliphatic chain fragments. The variation in response of pesticides in all matrices is presented in Figure 3.

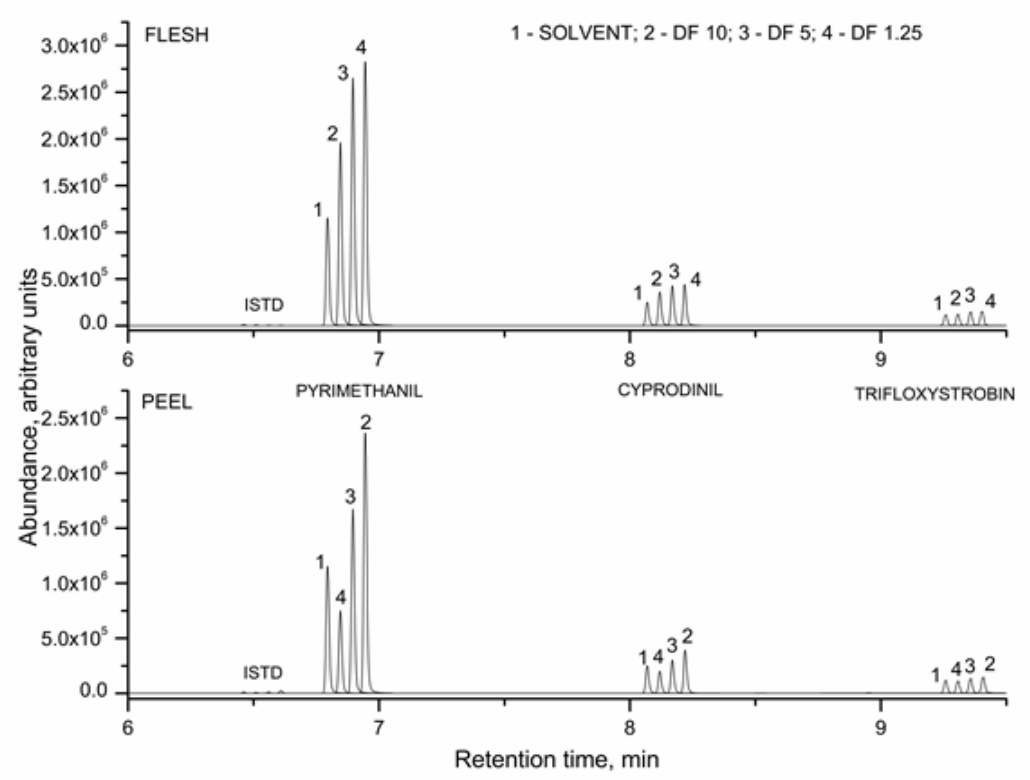

Figure 3. The comparison of peak intensities of $5 \mu \mathrm{g} \mathrm{mL}^{-1}$ pyrimethanil $(\mathrm{m} / \mathrm{z} 198)$, cyprodinil $(\mathrm{m} / \mathrm{z} 224)$ and trifloxystrobin $(\mathrm{m} / \mathrm{z} 116)$ obtained by injection in pure hexane and in matrix-based solutions different in concentration. Retention time offset between chromatograms is 0.05 minutes; chromatogram marked as 1 is shown without offset.

A positive matrix effect observed in the flesh extract can be explained by phenomena originally noticed and described by Erney et al. [3]. Co extractives compete with analytes for the injector active sites, causing transporting of a larger amount of analytes to the column. The initial negative matrix effect observed in the peel extract was possibly the consequence of evaporation and re condensation in the injector of much larger amounts of low-volatile waxes, with resulting fixation of analytes in the wax matrix or blocking of the entrance to the column and analyte loading. With the dilution of peel extracts, the concentration of waxes decreases, probably falling outside the level critical for analytes fixation or obstruction of analyte loading, after which a protective role of co-extractives through interaction with the injector prevail again.

There are several approaches commonly used to overcome the matrix effect in the analysis. Since this phenomenon is a consequence of diverse interactions of analytes and co-extractives with injector active sites, the first choice is the use of analyte protectants. These compounds, usually rich in hydroxyl functional groups due to the hydrogenbonding ability strongly interact with active sites in the GC system, in both the inlet and the chromatographic column, and therefore have a protective role towards analytes. The mixtures of triglycerol and D-ribonic acid- $y$-lactone
[15] and ethyl glycerol, gulonolactone and sorbitol [16] demonstrated the satisfactory pesticides protection during GC analysis. Since the matrix effect changes from one sample to another, i.e. depends on the matrix type, some authors have suggested the application of the matrixmatched calibration method [11], which is considered as one of the most practical solutions. When no blank matrix is available for the matrix-matched calibration procedure, a standard-addition method is performed [17]. In the case of uncomplete matrix effect elimination with the aim of matrix-matching, the combination of matrix-matching and multiple isotopically labeled internal standards showed satisfactory results [18].

\section{Conclusion}

The response of trifloxystrobin could be considered unaffected in both peel and flesh extracts of Granny Smith apple variety and unchanged with dilution. However, the response of pyrimethanil and cyprodinil in both matrices was significantly more different than in the pure solvent. A more pronounced matrix effect was observed for the slightly polar pesticide - pyrimethanil. In undiluted flesh, the extract matrix effect reached $154 \%$ for pyrimethanil and $76 \%$ for cyprodinil. In the undiluted peel extract, the 
values were $-49 \%$ for pyrimethanil and $-30.2 \%$ for cyprodinil. Differences between ME values in peel and flesh extracts originate from diverse matrix types, presumably different in content of low-volatile waxes. After the matrix dilution, the response variation of pyrimethanil and cyprodinil remained noticeable. The final matrix dilution resulted in about 2-times lower response variation for both pesticides in flesh extract-based standards, while in peel extract-based standards the manifestation of inversion was observed. In conclusion, in GC/MS analysis of pyrimethanil and cyprodinil in apples, a strong matrix effect is present. Therefore, for reliable quantification procedures and overall analysis, the matrix-matched calibration should be applied.

\section{Acknowledgment}

This study was supported by the Ministry for Education, Science and Technological Development of the Republic of Serbia and was performed as part of Project TR 31060.

\section{References}

[1] H. Stahnke, S. Kittlaus, G. Kempe, L. Alder, Reduction of Matrix Effects in Liquid Chromatography-Electrospray Ionization-Mass Spectrometry by Dilution of the Sample Extracts: How Much Dilution is Needed?, Analytical Chemistry, 84(3) (2012) 1474-1482.

[2] J. Hajšlová, J. Zrostlíková, Matrix effects in (ultra)trace analysis of pesticide residues in food and biotic matrices, Journal of Chromatography A, 1000(1-2) (2003) 181-197.

[3] D. R. Erney, A. M. Gillespie, D. M. Gilvydis, C. F. Poole, Explanation of the matrix-induced chromatographic response enhancement of organophosphorus pesticides during open tubular column gas chromatography with splitless or hot on-column injection and flame photometric detection, Journal of Chromatography A, 638(1) (1993) 57-63.

[4] F. A. de Sousa, A. I. Guido Costa, M. E. Lopes Ribeiro de Queiroz, R. F. Teófilo, A. A. Neves, G. P. de Pinho, Evaluation of matrix effect on the $\mathrm{GC}$ response of eleven pesticides by PCA, Food Chemistry, 135(1) (2012) 179-185.

[5] J. Wu, H. Gao, L. Zhao, X. Liao, F. Chen, Z. Wang, X. Hu, Chemical compositional characterization of some apple cultivars, Food Chemistry, 103(1) (2007) 88-93.

[6] M. Persic, M. Mikulic-Petkovsek, A. Slatnar, R. Veberic, Chemical composition of apple fruit, juice and pomace and the correlation between phenolic content, enzymatic activity and browning, LWT - Food Science and Technology, 82 (2017) 23-31.

[7] L. Raudone, R. Raudonis, M. Liaudanskas, V. Janulis, P. Viskelis, Phenolic antioxidant profiles in the whole fruit, flesh and peel of apple cultivars grown in Lithuania, Scientia Horticulturae, 216 (2017) 186-192.

[8] F. A. de Sousa, A. I. Guido Costa, M. E. Lopes Ribeiro de Queiroz, R. F. Teófilo, G. P. de Pinho, A. A. Neves, Influence of $\mathrm{pH}$ and Matrix Components in the Chromatographic Response of Pesticides, Chromatographia, 76(1-2) (2013) 67-73.

[9] M. Stamenković, GC/MS analiza pesticida: Procena matriks efekta u ekstraktima jabuke na bazi različitih rastvarača. MSc Thesis, Dept of Chemistry, University of Niš, 2018.

[10] C. F. Poole, Matrix-induced response enhancement in pesticide residue analysis by gas chromatography, Journal of Chromatography A, 1158(1-2) (2007) 241-250.

[11] S. de Sousa Freitas, F. M. Lancas, Matrix effects observed during pesticides residue analysis in fruits by GC, Journal of Separation Science, 32(21) (2009), 3698-3705.

[12] J. Leide, A. X. de Souza, I. Papp, M. Riederer, Specific characteristics of the apple fruit cuticle: Investigation of early and late season cultivars 'Prima' and 'Florina' (Malus domestica Borkh.), Scientia Horticulturae, 229 (2018) 137-147.

[13] G. Giacinti, C. Raynaud, S. Capblancq, V. Simon, Evaluation and prevention of the negative matrix effect of terpenoids on pesticides in apples quantification by gas chromatography-tandem mass spectrometry, Journal of Chromatography A, 1483 (2017) 8-19.

[14] B. Klein, F. R. Thewes, A. R. de Oliveira, A. Brackmann, J. S. Barin, A. J. Cichoski, R. Wagner, Development of dispersive solvent extraction method to determine the chemical composition of apple peel wax. Food Research International, (2018) In Press.

[15] Y. Li, X. Chen, C. Fan, G. Pang, Compensation for matrix effects in the gas chromatography-mass spectrometry analysis of 186 pesticides in tea matrices using analyte protectants, Journal of Chromatography A, 1266 (2012) 131-142.

[16] K. Maštovská, S. J. Lehotay, M. Anastassiades, Combination of analyte protectants to overcome matrix effects in routine GC analysis of pesticide residues in food matrixes, Analitical Chemistry, 77 (2005) 8129 - 8137.

[17] A. G. Frenich, J. L. Martínez Vidal, J. L. Fernández Moreno, R. Romero-González, Compensation for matrix effects in gas chromatography-tandem mass spectrometry using a single point standard addition, Journal of Chromatography A, 1216 (2009) 4798-4808.

[18] T. Tsuchiyama, M. Katsuhara, M. Nakajima, Compensation of matrix effects in gas chromatography-mass spectrometry analysis of pesticides using a combination of matrix matching and multiple isotopically labeled internal standards, Journal of Chromatography A, 1524 (2017) 233-245. 


\section{Izvod \\ UTICAJ MATRIKS EFEKTA NA GC/MS ODZIV STANDARDA CIPRODINILA, PIRIMETANILA I TRIFLOKSISTROBINA U EKSTRAKTIMA JABUKE}

Milica D. Branković ${ }^{1}$, Darko H. Anđelković1 ${ }^{\text {, Hristina R. Kocić2 }}$, Gordana M. Kocić2

1 Univerzitet u Nišu, Prirodno-matematički fakultet, Departman za hemiju, Niš, Srbija

2Univerzitet u Nišu, Medicinski fakultet, Niš, Srbija

Za analizu pesticida u voću i povrću, jedna od najčešće primenjivanih instrumentalnih tehnika je gasna ili tečna hromatografija sa masenom spektrometrijom. Problem koji se javlja u analizi pesticida u ovako složenim uzorcima je promenljivost hromatografskog signala analita, do koje dolazi usled interakcija analita sa ko-ekstraktovanim komponentama matriksa. Veličina koja karakteriše ovakve promene signala je matriks efekat i može se proceniti poređenjem signala jedne te iste koncentracije analita u čistom rastvaraču i u ekstraktu uzorka. U ovom eksperimentu praćeno je ponašanje odziva standarda pirimetanila, ciprodinila i trifloksistrobina, koncentracije $5 \mu \mathrm{g} \mathrm{mL}^{-1}$ pripremljenog u heksanu i pripremljenog sa različitim udelima heksanskih ekstrakta kore i pulpe Greni Smit jabuke. Odziv trifloksistrobina se nije značajno promenio ni u jednom od matriksa, dok je znatno drugačiji odziv pirimetanila i ciprodinila uočen i u ekstraktima kore i u ekstraktima pulpe jabuke. U nerazblaženom ekstraktu pulpe, vrednosti matriks efekta su 154 i $76 \%$ za pirimetanil i ciprodinil, respektivno. U nerazblaženom ekstraktu kore, vrednosti su $-49 \%$ za pirimetanil i $-30,2 \%$ za ciprodinil. Promena u odzivu pesticida ostaje značajna, čak i nakon razblaživanja ekstrakta. Finalno razblaženje je rezultovalo dva puta slabijom promenom odziva za oba pesticida u standardnim rastvorima na bazi ekstrakta pulpe, dok je u standardnim rastvorima na bazi ekstrakta kore došlo do promene vrednosti matriks efekta iz negativne u pozitivnu.
(ORIGINALNI NAUČNI RAD) UDK 632.95.02:543.5:634.11

KIjučne reči: GC/MS; matriks efekat; jabuke 